Ten years later (1878) the writer of this notice had the pleasure to accompany Mr. Lee to the Eifel district, where, being happily ioined by Prof. Ferdinand Roemer, of Breslau, the historian of the Deronian rocks of this region, a delightful fortnight was spent in collecting the fossils of Gerolstein, Prüm, and other localities.

Mr. Lee contributed several important papers to the Grocogical Magazine on points in Devonian geology which he had worked out; he was the original discoverer of many fossils described by the late Mr. J. W. Salter, F.G.S. (as Homalonotus Johannis, etc.)

He gave his most valuable and extensive collection, contained in 31 cabinets and comprising upwards of 21,000 specimens, to the British Museum (Natural History), in 1885. This collection not only embraces a large series of British fossils from all formations, many of which have been figured and described, but a most valuable and instructive collection from almost every important European locality where fossils abound.

Althongh his bodily powers began of late years to fail, his intellect remained bright, especially on all matters of science, to the last, and after be failed to write. he dictated and signed many letters, giving clear and accurate scientific information to correspondents, and he was full of plans and ideas for the furtherance of science up to the end.

Mr. Lee was a Member of the British Association, a Fellow of the Society of Antiquaries, and a Fellow of the Geological Society of London.

\title{
SIR WILLIAM VERNON GUISE, BART., F.L.S., F.G.S.
} Born 1816, Died 1887.

Sir William Guise was the eldest son of the late Gen. Sir John Wright Guise, Bart., one of the most distinguished Peninsula officers, by his marriage with Charlotte Diana, daughter of the late John Vernon, Esq., of Clontarf Castle, County Dublin. He was born in the year 1816, and succeeded to his father's title in 1865 . He was a Magistrate and Deputy-Lieutenant for Gloucestershire, and served as High Sheriff of that county in 1872 . He was also a retired Lieutenant-Colonel of the Royal South Gloncestershire Militia. Sir William married in 1844, Margaret Anna Maria, daughter of the Rev. D. H. Lee-Warner, of Walsingham Abbey. He is succeeded by his eldest surviving son, William Francis George, who was born in 1851 .

Sir William Guise was elected a Fellow of the Geological Society in 1841; and although not a founder, was for many years one of the most active members of the Cotteswold Naturalists' Field Club. Only last year he retired from the office of President, which he had held for 28 years. He had a wide general knowledge of Geology, Conchology, Botany, and Archæology, and there were few objects or places of in terest in Gloucestersbire with which he was not acquainted: thus he was eminently qualified to direct the Excursions of the Club, while his hearty and genial manners contributed much to the enjoyment of the meetings. Sir William Guise died on the 24th September, at his residence, Elmore Court, near Gloncester. 